\title{
RESPIRATORY ACTIVITY IN WHEAT SEEDS AS RELATED TO PHYSIOLOGICAL QUALITY
}

\author{
ATIVIDADE RESPIRATÓRIA EM SEMENTES DE TRIGO CORRELACIONADA COM \\ A QUALIDADE FISIOLÓGICA
}

\section{Juliana DODE ${ }^{1}$; Andréia da Silva ALMEIDA ${ }^{2}$; Cristiane DEUNER ${ }^{2}$; Carolina Terra BORGES ${ }^{2}$; Géri Eduardo MENEGHELLO² ${ }^{2}$ Francisco Amaral VILLELA²; Dario Munt de MORAES ${ }^{3}$}

1. Cerest Macrosul Pelotas - Centro de Referência em Saúde do Trabalhado, Pelotas, RS, Brasil; 2. PPG em Ciência e Tecnologia de Sementes, Faculdade de Agronomia Eliseu Maciel, Universidade Federal de Pelotas, Pelotas, RS, Brasil. cdeuner@yahoo.com.br; 3. Departamento de Botânica, Instituto de Biologia, Pelotas, RS, Brasil.

\begin{abstract}
Seeds are a very important input for crops, and the use of low quality seeds and/or inadequate management affects the germination and hampers seedling emergence, which reduces the plant stand. There is a critical need for the development of rapid methods, which are both reliable and easy to perform, for evaluating the physiological potential of seeds. This would streamline the decision-making process regarding the management of lots and allow for the identification of seed lots of inadequate quality in the seed processing unit, which could then be discarded, and would consequently result in reduced costs associated with unnecessary processing. However, it is important that these methods are low cost and quick to perform. The aim of this study was to evaluate the correlation of respiratory activity of wheat seed, through Pettenkofer test, with tests that evaluate seeds physiological quality. We selected a seed lot of high physiological quality, then subjected the seeds to adverse temperature and relative humidity conditions to obtain different vigor levels. The adverse conditions used were $42^{\circ} \mathrm{C}$ and $100 \%$ relative humidity, for periods of $6,36,66$ and 96 hours. This process obtained seeds of five vigor levels which were subjected to the following tests: germination, field emergence, electrical conductivity, shoot and root length, total dry mass and respiratory activity. The results showed a negative correlation between respiratory activity and germination, emergence, shoot and root length and dry weight, whereas germination and emergence were strongly correlated with respiratory activity, $r=-0.86$ and $r=-0.81$, respectively. There was a significant positive correlation between conductivity and respiratory activity. Therefore, the respiratory activity test using the Pettenkofer method was correlated with other vigor tests, and allowed the classification of wheat seeds into lots of different levels of quality.
\end{abstract}

KEYWORDS: Triticum aestivum L. Pettenkofer method. Vigor.

\section{INTRODUCTION}

Wheat (Triticum aestivum L.) grass is grown worldwide and is the second largest cereal crop, being of great importance for human and animal nutrition. In Brazil, the cultivation area for wheat is 2.5 million hectares, particularly in the states of Rio Grande do Sul and Paraná, with the production of 1919 and 169 thousand tons, respectively (CONAB, 2015).

Seeds are an important input for the crop, as the use of high quality seeds provide a more rapid and uniform emission of the primary root during germination, producing seedlings with a larger initial size which results in higher growth and grain yields (MIELEZRSKI et al., 2008; MUNIZZI et al., 2010).

The term "seed quality" involves physical, physiological and sanitary characteristics, and when these characteristics are examined together they provide an indication of the value and the potential use of a seed lot. Germination and vigor tests are used to evaluate the physiological quality of seeds (MARCOS FILHO, 2005).

One characteristic to be considered during the germination test is the time period for its performance, which requires between 7 and 28 days to obtain the results for most species. The length of this period determines the commercial interest in the seeds. In contrast, the vigor of the seed, which is the sum of all attributes which favor the rapid and uniform stand establishment in the field (DELOUCHE; CALDWELL, 1960), provides more rapid results. However, the seed quality cannot always be completely rated by only one test, therefore, it is recommended to use various different tests to give a better idea of the physiological quality of a seed lot (SCHEEREN et al., 2010).

Rapid methods, which are both reliable and easy to perform, are required for the evaluation of the physiological potential of the seeds, in addition to streamlining the decision-making process regarding the management of lots (MERTZ et al., 2012). Quicker evaluation methods would allow 
seed lots of inadequate quality to be discarded in the seed processing unit, which would consequently saving on costs from unnecessary processing (MARCOS FILHO, 1999).

Martins et al. (2014) evaluated the separation of seed lots by their respiratory activity and concluded that it was an efficient method for the separation of soy and bean seed lots of different vigor levels. Similar results have also been reported for cotton seeds (VENSKE et al., 2014). Furthermore, as shown in a study by Marini et al. (2013), respiratory activity is indicative of reduced seed quality and can be used to identify factors which are related to seed deterioration.

This study aimed to evaluate the efficiency of the Pettenkofer method for the determination of respiratory activity, in order to differentiate between differences in the physiological quality of wheat seed lots. We also aimed to determine the correlation between respiratory activity and other vigor tests.

\section{MATERIAL AND METHODS}

The study was conducted in the Seed Laboratory and Greenhouse of the Federal University of Pelotas, Brazil. Wheat seeds from the CD 115 cultivar were obtained from the Agricultural Research Center of Temperate Climate (CPACT, EMBRAPA).

A seed lot with $94 \%$ germination was selected and subjected to adverse temperature and relative humidity conditions to obtain different vigor levels. The seeds were distributed in single layer on a stainless steel screen surface, which was installed inside gerbox-type plastic boxes. Water $(40 \mathrm{~mL})$ was added to each individual compartment. The boxes were capped and maintained in a BOD (Biochemical Oxigen Demand) incubator chamber at $42^{\circ} \mathrm{C}$ for either $6,33,66$ or 96 hours. Five vigor levels were obtained from this process, and each vigor level was divided into four sections, which were the replicates.

The physiological quality and respiratory activity of the lots were evaluated with the following tests: germination, field emergence, electrical conductivity, shoot and root length of the seedlings, total dry mass and respiratory activity.

\section{Germination test}

The germination test $(\mathrm{G})$ was performed with four groups of 200 seeds (four subgroups of 50), totaling 800 seeds per wheat seed lot. The seeds were distributed in germitest paper rolls which were moistened with distilled water at a ratio of 1:2.5 $\mathrm{w} / \mathrm{v}$, then maintained until germination at a temperature of $20^{\circ} \mathrm{C}$. Germination was evaluated on the fourth and eighth day after sowing, consistent with the method described by the Regras para Análises de Sementes-RAS (BRASIL, 2009), and the results were expressed as a percentage of normal seedlings.

\section{Field emergence}

The field emergence (FE) test used four groups of 50 wheat seeds per lot, totaling 200 seeds, which were sown in furrows $2 \mathrm{~m}$ in length and $5 \mathrm{~cm}$ deep. The results were expressed as the number of emerged seedlings 21 days after sowing.

\section{Electrical conductivity}

The electrical conductivity (EC) test used four groups of 50 seeds from the pure seed fraction, totaling 200 seeds per lot. The samples were weighed on a precision scale then placed for soaking in a plastic cup containing $75 \mathrm{~mL}$ of deionized water, shaken gently so that all seed were completely submerged, then kept in a germination chamber at $25^{\circ} \mathrm{C}$. Two readings were performed, one after 3 hours of soaking and another after 24 hours. The EC measurements were taken using a conductivimeter (CD-21, Digimed), and the results were expressed as $\mu \mathrm{S} \mathrm{m}^{-1} \mathrm{~g}^{-1}$ of seed (AOSA, 1983).

\section{Length of the shoot and root of the seedlings}

The length of the shoot (LS) and length of the root (LR) of the seedlings were measured as the average length of the aerial part and roots of normal seedlings obtained after sowing of four replicates of 10 seeds. The paper rolls containing the seeds remained in a germination chamber at $20^{\circ} \mathrm{C}$ for 7 days, after which the length of the seedlings was measured with a millimeter ruler. The values obtained for LS and LR were divided by the number of seedlings, and the results expressed as $\mathrm{mm}$ seedlings ${ }^{-1}$, according to Nakagawa (1999).

\section{Total dry mass}

The total dry mass (TDM) of the same 10 seedlings from each replicate was measured after placing the seedlings in a forced air oven at $70 \pm$ $2{ }^{\circ} \mathrm{C}$ to determine the constant mass. The results were expressed in $\mathrm{mg}$ seedling ${ }^{-1}$.

\section{Respiratory activity}

The respiratory activity (RA) of the seeds was measured by determining the $\mathrm{CO}_{2}$ released by the seeds with Pettenkofer equipment, which consisted of four gas washing flasks. Two of the flasks contained sodium hydroxide $(\mathrm{NaOH})$ at $25 \%$ 
to retain $\mathrm{CO}_{2}$ from the ambient air, one flask was used to store seeds in an environment free from $\mathrm{CO}_{2}$ in the ambient air, and another contained barium hydroxide $\mathrm{Ba}(\mathrm{OH})_{2}$ at $25 \%$, which reacts with $\mathrm{CO}_{2}$ produced from the respiratory activity of seeds to produce barium carbonate $\left(\mathrm{BaCO}_{3}\right)$. The flasks were connected with a silicone hose which was connected to an air suction tube. The air flow was regulated with a tap which allowed the speed to be controlled through the observation of bubbles formed in the flasks.

Seeds from the different lots $(100 \mathrm{~g})$ were placed in the storage flask for 60 minutes at $25^{\circ} \mathrm{C}$. After the measurement period, five aliquots of 10 $\mathrm{mL}$ were collected from the $\mathrm{BaCO}_{3}$ solution in an Erlenmeyer flask. Two drops of phenolphthalein reagent was placed in each flask, then titration with hydrochloric acid $(\mathrm{HCl}) 0.1 \mathrm{~N}$ was performed in a $50 \mathrm{~mL}$ burette. At the turning point, the $\mathrm{HCl}$ volume for each aliquot was recorded. This volume, which was directly related to the amount of $\mathrm{CO}_{2}$ fixed by the $\mathrm{Ba}(\mathrm{OH})_{2}$ solution, was used to calculate the respiratory activity of the seeds, measured as the fixed $\mathrm{CO}_{2}$ produced from respiration. However, it should be noted that the calculated amount is the $\mathrm{CO}_{2}$ content of the titrated aliquot.

Measurement of the respiratory activity of seeds was performed using the method described by Mendes et al. (2009), with some modifications. The calculation of respiratory activity was based on the following equation: $\mathrm{RA}=\mathrm{N} \times \mathrm{D} \times 22$ (MÜLLER, $1964)$, where $\mathrm{N}$ is the normality of the acid $(\mathrm{HCl}$; $0.1 \mathrm{~N}$ ), $\mathrm{D}$ is the difference between the volume of $\mathrm{HCl}$ used in the blank titration and the volume of
$\mathrm{HCl}$ used in the sample titration and 22 is the normality value for $\mathrm{CO}_{2}$. The result was expressed as the quantity of $\mathrm{CO}_{2}$ released per gram of seed per hour $\left(\mu \mathrm{g} \mathrm{CO}_{2}\right.$ seed $\left.\mathrm{g}^{-1} \mathrm{~h}^{-1}\right)$.

\section{Experimental design and statistical analysis}

This study used a completely randomized experimental design with four replicates in each group. The data obtained for each variable was subjected to analysis by analysis of variance (ANOVA) with Tukey's post-hoc test at a 5\% probability level. The data obtained from the germination tests, including the first counts for germination and field emergence were transformed into arcsen $\sqrt{ } \mathrm{x} / 100$. Simple correlation analyses was performed for each of the vigor tests with seed respiration.

\section{RESULTS AND DISCUSSION}

The results from the germination, field emergence, electrical conductivity, measurement of shoot and root length, total dry mass and respiratory activity tests are shown in Table 1. Significant differences were found between the results for seed lots of different vigor levels. The results from the $G$ test differed between lots over the five vigor levels, with the highest percentage of germination observed for lot 1 and the lowest observed for lot 5. In the FE test we were able to separate the lots into four of the five possible levels, and the difference between lot 1 and 4 was 27 percentage points (pp), however, the difference between the maximum and minimum germination was $42 \mathrm{pp}$.

Table 1. Germination (G), field emergency (FE), electrical conductivity (EC) with three and 24 hours of soaking, length of shoot part and root (LS; LR), total dry mass (TDM) and respiratory activity (RA) of five wheat seed lots, cultivar CD115.

\begin{tabular}{|c|c|c|c|c|c|c|c|c|}
\hline \multirow[t]{2}{*}{ Lots } & \multirow{2}{*}{$\begin{array}{c}\mathrm{G} \\
(\%)\end{array}$} & \multirow{2}{*}{$\begin{array}{l}\mathrm{FE} \\
(\%)\end{array}$} & \multicolumn{2}{|c|}{$\mathrm{EC}\left(\mu \mathrm{S} \mathrm{m}^{-1} \mathrm{~g}^{-1}\right)$} & \multirow{2}{*}{$\begin{array}{l}\mathrm{LS}(\mathrm{mm} \\
\text { seedling }\end{array}$} & \multirow{2}{*}{$\begin{array}{l}\mathrm{LR}(\mathrm{mm} \\
\text { seedling }\end{array}$} & \multirow{2}{*}{$\begin{array}{l}\text { TDM (mg } \\
\left.\text { seedling }^{-1}\right)\end{array}$} & \multirow{2}{*}{$\begin{array}{c}\mathrm{RA} \\
\left(\mu \mathrm{g} \mathrm{CO}_{2} \mathrm{~g}^{-1}\right. \\
\text { seed })\end{array}$} \\
\hline & & & $3 \mathrm{~h}$ & $24 \mathrm{~h}$ & & & & \\
\hline 1 & $94 \mathrm{a}$ & $96 \mathrm{a}$ & $10,8 \mathrm{a}$ & $21,6 \mathrm{bc}$ & $95 \mathrm{a}$ & $67 a$ & $0,4 \mathrm{a}$ & $0,3 \mathrm{a}$ \\
\hline 2 & $89 \mathrm{~b}$ & $90 \mathrm{~b}$ & $10,9 \mathrm{a}$ & $20,5 \mathrm{c}$ & $90 \mathrm{ab}$ & $72 \mathrm{a}$ & $0,2 \mathrm{~b}$ & $0,9 \mathrm{ab}$ \\
\hline 3 & $79 c$ & $86 \mathrm{~b}$ & $11,3 \mathrm{ab}$ & $21,1 \mathrm{bc}$ & $81 \mathrm{~b}$ & $66 a$ & $0,1 \mathrm{c}$ & $1,1 \mathrm{ab}$ \\
\hline 4 & $59 \mathrm{~d}$ & $79 c$ & $12,6 \mathrm{bc}$ & $24,2 \mathrm{~b}$ & $68 \mathrm{c}$ & $60 \mathrm{a}$ & $0,09 \mathrm{~cd}$ & $1,8 \mathrm{bc}$ \\
\hline 5 & $40 \mathrm{e}$ & $54 \mathrm{~d}$ & $13,6 \mathrm{c}$ & $28,4 \mathrm{a}$ & $31 \mathrm{~d}$ & $34 \mathrm{~b}$ & $0,04 \mathrm{~d}$ & $2,3 \mathrm{c}$ \\
\hline $\begin{array}{l}\mathrm{CV} \\
(\%)\end{array}$ & 2,79 & 2,76 & 5,99 & 6,33 & 7,43 & 18,17 & 22,68 & 17,18 \\
\hline
\end{tabular}

*Averages followed by the same letter in the column do not differ to each other by Tukey test at 5\% of probability.

The electrical conductivity detected after three hours of soaking showed that lots 1 and 2 were the highest quality due to reduced leaching of exudates to the soaking medium. However, after 24 hours of soaking, lot 2 was classified as being the highest quality. For both periods ( 3 and 24 hours), 
the EC test was sensitive enough to detect that lot 5 was the lowest quality compared to the other evaluated lots.

The EC test has been recognized as an effective way to evaluate seed vigor in various species, including black oats (MENEZES et al., 2007), popcorn (RIBEIRO et al., 2009) and white oats (SPONCHIADO et al., 2014). However, this was not found to be an efficient option for determining quality differences between sorghum seed lots (SOARES et al., 2010) or castor bean seed lots (MENDES et al., 2010) of different vigor levels. In some cases, the failure of this test has been attributed to the genotype, which is associated with differences in seed coat characteristics, allowing different amounts of leachate to be released (MARCOS FILHO, 2005).

According to Perry (1977), the seedling length indicates the activity level and metabolism coordination of germination, and therefore, the vigor of the seed. The shoot length results are presented in Table 1, where lots 1, 2 and 3 were determined to have high vigor, lot 4 was medium and lot 5 was low vigor. However, only lot 5 was lower than the others for root length. In general, the process of evaluating the vigor of a seed lot is completed using various tests, each of which have different rating systems. In this study it did not appear that root development was affected by the detrimental conditions as much as the development of other parts, e.g. the shoot.

The results for dry mass allowed for the separation of lots according to vigor levels, where lots 1 and 2 were the highest quality and lot 5 was the lowest, confirming the results found for the tests of field emergence, electrical conductivity and length of shoot. Bortolotto et al. (2008) also observed that lots of two cultivars of rice seeds were able to be stratified using the dry mass test. Conversely, Braz and Rossetto (2009) observed that the dry mass test was not able to differentiate between five lots of sunflower seeds, however, lots were able to be differentiated in other tests, such as the field emergence test.

Similarly, the test of respiratory activity was an efficient test for the separation of lots into three levels, with lot 1 considered to be high vigor, lot 5 to be low vigor and lots 2,3 and 4 to be medium vigor. For the germination, field emergence, shoot length and seedling dry mass tests, lot 1 was found to be superior to the others.
According to Delouche and Baskin (1973), the deterioration of seeds occurs gradually, manifesting in a sequence of events of biochemical or physiological origin, such as damage to the membrane permeability systems. This is the first deterioration event to appear, and has a strong relationship with the respiratory rate of the tissues, including changes in enzymatic activity, a decrease in tissue reserves, reduced speed and capacity of germination and decreased growth of normal seedlings. Therefore, deteriorated wheat seeds have reduced vigor and increased respiratory activity.

The results from the RA test are in agreement with the hypothesis of Amaral and Peske (1984), who suggested that deteriorated seeds release greater amounts of solutes and $\mathrm{CO}_{2}$ than high quality seeds. It is also consistent with the work of Bopper and Kreese (2010), emphasizing that lower quality seeds consume less oxygen in the early stages of the germination process.

In contrast, Mendes et al. (2009), noted that when rice and soybean seeds were soaked in water for one hour, the respiratory activity was higher with increasing levels of lot vigor. Following seed rehydration, the initial metabolic activity is an increase in respiration, which increases from extremely low to high levels shortly after imbibition begins (POPINIGIS, 1985; FERREIRA; BORGHETTI, 2004).

When the relationship between respiratory activity and the other tests for evaluating the physiological quality of wheat seeds were compared (Table 2), a negative correlation was found between respiratory activity and the results from the germination, emergence, shoot and root length and dry mass results, whereas the results from the germination and field emergence tests were strongly correlated, $r=-0.86$ and $r=-0.81$, respectively. On the other hand, the length of the root had a lower correlation $(r=-0.59)$. Dode et al. (2013) and Marini et al. (2013) also showed a negative correlation between respiration and vigor for sunflower and rice seeds, respectively, which can be explained by the fact that seeds in an advanced process of decay have a higher metabolism, possibly seeking to reorganize its cellular machinery in order to increase respiratory activity (VENSKE et al., 2014). In watermelon seeds, Oliveira et al. (2015) found that the respiratory activity allowed the separation of seeds lots, but there were no positive or significant correlations with other vigor tests. 
Table 2. Correlation coefficient between respiratory activity (RA) and physiological quality tests of wheat seeds, cv. CD115

\begin{tabular}{cc}
\hline Tests & RA \\
\hline G & $-0,86^{* *}$ \\
FE & $-0,81^{* *}$ \\
LS & $-0,76^{* *}$ \\
LR & $-0,59^{* *}$ \\
TDM & $-0,72^{* *}$ \\
EC 3H & $0,65^{* *}$ \\
EC 24H & $0,73^{* *}$ \\
\hline
\end{tabular}

${ }^{1} \mathrm{G}=$ germination in sand; FE= field emergency; LS = length of shoot part; LR = length of root; TDM = total dry matter; EC $3 \mathrm{H}=$ electrical conductivity 3 hours; EC $24 \mathrm{H}=$ electrical conductivity 24 hours; ${ }^{\mathrm{nn}}=$ not significant, $* *=$ significant at $1 \%$ of probability, $*=$ significant at $5 \%$, by the $\mathrm{r}$ test.

The correlation between respiration and electrical conductivity after 3 and 24 hours of soaking was significant and positive, with $\mathrm{r}=0.65$ and $\mathrm{r}=0.73$, respectively, therefore, the amount of leachate increases with seed respiration.

Overall, the respiratory activity test was correlated with the physiological quality of seeds, and therefore, could potentially be used to quickly estimate the quality, consistent with results found for cotton seeds (VENSKE et al., 2014), soybean seeds (MENDES et al., 2009) and sunflower seeds (DODE et al., 2012).

\section{CONCLUSION}

The respiratory activity test using the Pettenkofer method was correlated with other vigor tests, and allowed the classification of wheat seeds into lots of different levels of quality.

RESUMO: As sementes são um atributo muito importante para a cultura, sendo que o uso de sementes de baixa qualidade e/ou a gestão inadequada afeta a germinação e dificulta a emergência das plântulas, reduzindo o estande de plantas. A necessidade de métodos rápidos, confiáveis e de fácil execução é fundamental para a avaliação do potencial fisiológico das sementes. Eles poderiam agilizar as tomadas de decisões referentes ao manejo dos lotes e permitir o descarte de lotes de sementes com qualidade inadequada, na unidade de recepção e processamento de sementes, com a consequente redução de custos de um provável processamento desnecessário. Entretanto, é importante que os mesmos sejam de baixo custo e consideravelmente rápidos. O objetivo do presente trabalho foi correlacionar a atividade respiratória de sementes de trigo, através do teste de Pettenkofer, com testes que avaliam a qualidade fisiológica das sementes. Foi selecionado um lote de sementes com alta qualidade fisiológica e as mesmas foram submetidas a condições adversas de temperatura e umidade relativa do ar para obter diferentes níveis de vigor. As condições adversas foram de 42 ${ }^{\circ} \mathrm{C}$ e $100 \%$ de umidade relativa, por períodos de seis, 36, 66 e 96 horas. Com o processo obteve-se cinco níveis de vigor e estas sementes foram submetidas aos seguintes testes: germinação, emergência a campo, condutividade elétrica, comprimento de parte aérea e raiz, massa seca total e atividade respiratória. Os resultados mostraram correlação negativa entre a atividade respiratória e os testes de germinação, emergência, comprimento da parte aérea e da raiz, e massa seca, sendo que o teste de germinação e a emergência apresentaram alta correlação com a atividade respiratória, $r=-0,86$ e $r=$ 0,81 , respectivamente. Já a correlação da condutividade elétrica com a respiração foi significativa e positiva. Portanto, conclui-se que o teste da atividade respiratória pelo método de Pettenkofer se correlaciona com outros testes de vigor e permite a classificação dos lotes de sementes de trigo em diferentes níveis de qualidade.

PALAVRAS-CHAVE: Triticum aestivum L. Método de Pettenkofer. Vigor.

\section{REFERENCES}

AMARAL, A. S.; PESKE, S. T. pH do exsudato para estimar, em 30 minutos, a viabilidade de sementes de soja. Revista Brasileira de Sementes, Brasília, v. 6, n. 3, p. 85-92, 1984.: Available in: http://www.scielo.br/scielo.php?script=sci_nlinks\&ref=000083\&pid=S01013122200200010001900001\&lng=en Access: 10 jan. 2016 
ASSOCIATION OF OFFICIAL SEED ANALYSIS - AOSA (1983). Seed vigour handbook. The handbook of seed testing. East Lansing, 88p.

BOPPER, S.; KREESE, M. (2010) Development of a non-destructive germination test by measuring seed oxygen consumption. ISTA Congress, 29, 2010. Cologne. Seed Symposium Abstracts. Cologne: ISTA, p. 1, p. 24

BORTOLOTTO, R. P.; MENEZES, N. L. de; GARCIA, D. C.; MATTIONI, N. M. Teor de proteína e qualidade fisiológica de sementes de arroz. Bragantia, Campinas, v. 67, n. 2, p. 513-520, 2008. Available in: http://www.scielo.br/pdf/brag/v67n2/a28v67n2.pdf Access: 10 jun. 2016

BRAZ, M. R. S.; ROSSETTO, C. A. V. Correlação entre testes para avaliação da qualidade de sementes de girassol e emergência das plântulas em campo. Ciência Rural, Santa Maria, v. 39, n. 7, p. 2004-2009, 2009. Available in: http://www.scielo.br/scielo.php?pid=S0103-84782009000700008\&script=sci_arttext Access: 10 jan. 2016

BRASIL. Ministério da Agricultura, Pecuária e Abastecimento. Regras para análise de sementes. Brasília: MAPA, 2009. 399p.

CONAB. Acompanhamento da safra brasileira de grãos, v. 3- Safra 2015/16 - segundo levantamento, Brasília, p. 1-166, novembro 2015. Available in:

http://www.conab.gov.br/OlalaCMS/uploads/arquivos/15_11_16_15_18_26_safras_nov_2015.pdf Access: 10 jan. 2016

DELOUCHE, J.C.; BASKIN, C.C. Accelerated aging techniques for predicting the relative storability of seed lots. Seed Science and Technology, v.1, p.427-452, 1973.

DELOUCHE, J. C.; CADWELL, W. P. Seed vigor and vigor test. Proceedings of the Association of Official Seed Analysts, v. 50, n. 1, p. 124-129, 1960. Available in: http://www.scielo.br/scielo.php?script=sci_nlinks\&ref=000109\&pid=S01013122200600010001500003\&lng=en Access: 18 dez. 2015

DODE, J. de S.; MENEGHELLO, G. E.; MORAES, D. M. de; PESKE, S. T. Teste de respiração para avaliar a qualidade fisiológica de sementes de girassol. Revista Brasileira de Sementes, Londrina, v. 34, n. 4 p. 686691, 2012. Available in: http://www.scielo.br/scielo.php?script=sci_arttext\&pid=S0101-31222012000400021 Access: 18 dez. 2015

DODE, J. de S.; MENEGHELLO, G. E.; TIMM, F. C.; MORAES, D. M. de; PESKE, S. T. Teste de respiração em sementes de soja para avaliação da qualidade fisiológica. Ciência Rural, Ciência Rural, v. 43, n. 2, p. 193198, 2013. Available in: http://www.scielo.br/pdf/cr/v43n2/a3613cr5997.pdf Access: 05 dez. 2015

FERREIRA, A. G.; BORGHETTI, F. Germinação: do básico ao aplicado. Porto Alegre: Artmed, 2004. 323p.

MARCOS FILHO, J. Fisiologia de sementes de plantas cultivadas. Piracicaba: Fealq, 2005. 495p.

MARCOS FILHO, J. Testes de vigor: importância e utilização. In: KRZYZANOWSKI, F. C.; VIEIRA, R. D.; FRANÇA NETO, J. B. (Ed.). Vigor de sementes: conceitos e testes. Londrina: ABRATES, 1999. p. 1.1-1.21.

MARINI, P.; MORAES, C. L.; LARRÉ, C. F.; LIMA, M. C.; MORAES, D. M. de; AMARANTE, L. do. Indicativos da perda de qualidade de sementes de arroz sob diferentes temperaturas através da atividade enzimática e respiratória. Interciência, Caracas, v. 38, n. 1, p. 54-59, 2013. Available in: http://www.redalyc.org/articulo.oa?id=33926506002 Access: 05 dez. 2015 
MENDES, C. R.; MORAES, D. M.; LIMA, M. G. S.; LOPES, N. F. Respiratory activity for the differentiation of vigor on soybean seeds lots. Revista Brasileira de Sementes, Brasília, v. 31, p. 171-176, 2009. Available in: http://www.scielo.br/scielo.php?script=sci_arttext\&pid=S0101-31222009000200020 Access: 05 dez. 2015

MENDES, R. C.; DIAS, D. C. F. S.; PEREIRA, M. D.; DIAS. L. A. S. Testes de vigor para avaliação do potencial fisiológico de sementes de mamona (Ricinus communis L.). Ciência e Agrotecnologia, Lavras, v. 34, n. 1, p. 114-120, 2010. Available in: http://www.scielo.br/scielo.php?script=sci_arttext\&pid=S141370542010000100015 Access: 14 dez. 2015

MENEZES, N. L.; GARCIA, D. C.; BAHRY, C. A.; MATTIONI, N. M. Teste de condutividade elétrica em sementes de aveia preta. Revista Brasileira de Sementes, Pelotas, v. 29, p. 138-142, 2007. Available in: http://www.scielo.br/scielo.php?script=sci_nlinks\&ref=000098\&pid=S01013122200900030000800012\&lng=en Access: 14 dez. 2015

MERTZ, L. M.; SEGALIN, S. R.; HUTH, C.; ROSA, T. A. Condutividade elétrica individual para a avaliação do potencial fisiológico de sementes de trigo. Informativo Abrates, Pelotas, v. 22, p. 35-39, 2012. Available in: http://www.abrates.org.br/images/stories/informativos/v22n1/Artigo_11.pdf Access: 14 dez. 2015

MIELEZRSKI, F.; SCHUCH, L. O. B.; PESKE, S. T.; PANOZZO, L. E.; CARVALHO, R. R.; ZUCHI, J. Desempenho em campo de plantas isoladas de arroz híbrido em função da qualidade fisiológica das sementes. Revista Brasileira de Sementes, Pelotas, v. 30, n. 3, p. 139-144, 2008. Available in: http://www.scielo.br/scielo.php?script=sci_arttext\&pid=S0101-31222008000300018 Access: 10 jun. 2016

MÜLLER, L. E. Manual de laboratório de fisiologia vegetal. Instituto Interamericano de Ciências Agricolas de la O. E. A. Turrialba, Costa Rica, 1964. 165p.

MUNIZZI, A.; BRACCINI, A. de L. E.; RANGEL, M. A. S.; SCAPIM, C. A.; BARBOSA, M. C.; ALBRECHT, L. P. Qualidade de sementes de quatro cultivares de soja, colhidas em dois locais no estado de Mato Grosso do Sul. Revista Brasileira de Sementes, Brasília, v. 32, n. 1, p. 176-185, 2010. Available in: http://www.scielo.br/pdf/rbs/v32n1/v32n1a20.pdf Access: 10 jun. 2016

NAKAGAWA, J. Testes de vigor baseados no desempenho das plântulas. In: KRZYZANOWSKI, F. C.; VIEIRA, R. D.; FANÇA NETO, J. B. (Ed.). Vigor de sementes: conceitos e testes. Londrina: ABRATES, 1999, p. 1-24.

OLIVEIRA, L. M. de; CAVALHEIRO, V. B. D.; MORAES, D. M. de; TILMANN, M. A. A.; SCHUCH, L. O. B. Medição do $\mathrm{CO} 2$ como método alternativo para a diferenciação do vigor de lotes de sementes de melancia. Ciência Rural, Santa Maria, v. 45, n. 4, p. 606-611, 2015. Available in: http://www.scielo.br/pdf/cr/2014nahead/0103-8478-cr-00-00-cr-20130594.pdf Access: 05 dez. 2015

PERRY, D. A. A vigour test for seeds of barley (Hordeum vulgares) based on measurement of plumule growth. Seed Science and Technology, v. 5, n. 1, p. 709-719, 1977.

POPINIGIS, F. Fisiologia da semente. Brasília, AGIPLAN, 1985. 289p.

RIBEIRO, D. M.; BRAGANÇA, S. M.; GONELI, A. L. D.; DIAS, D. C. F. S.; ALVARENGA, E. M. Teste de condutividade elétrica para avaliar o vigor de sementes em milho-pipoca (Zea mays L.). Revista Ceres, Viçosa, v. 56, n. 6, p. 772-776, 2009. Available in:

http://www.ceres.ufv.br/ojs/index.php/ceres/article/viewFile/3503/1393 Access: 14 dez. 2015

SCHEEREN, B. R.; PESKE, S. T.; SCHUCH, L. O. B.; BARROS, A. C. A. Qualidade fisiológica e produtividade de sementes de soja. Revista Brasileira de Sementes, Brasília, v. 32, n. 3, p. 35-41, 2010. Available in: http://www.scielo.br/pdf/rbs/v32n3/v32n3a04.pdf Access: 05 dez. 2015 
SPONCHIADO, J. C.; SOUZA, C. A.; COELHO, C. M. M. Teste de condutividade elétrica para determinação do potencial fisiológico de sementes de aveia branca. Semina: Ciências Agrárias, Londrina, v. 35, n. 4, suplemento, p. 2405-2414, 2014. Available in:

http://www.uel.br/revistas/uel/index.php/semagrarias/article/view/14757 Access: 10 jan. 2016

SOARES, M. M.; CONCEIÇÃO, P. M. da; DIAS, D. C. F. dos S.; ALVARENGA, E. M. Testes para avaliação do vigor de sementes de sorgo com ênfase à condutividade elétrica. Ciência e Agrotecnologia, Lavras, v. 34, n. 2, p. 391-397, 2010. Available in: http://www.scielo.br/scielo.php?pid=S1413-

70542010000200017\&script=sci_arttext Access: 05 dez. 2015

VENSKE, E.; ABREU JÚNIOR, J. de S.; SOUSA, A. de M. de; MARTINS, L. F.; MORAES, D. M. de.

Atividade respiratória como teste de vigor em sementes de algodão. Revista Brasileira de Ciências Agrárias, Recife, v. 9, n. 2, p. 174-179, 2014. Available in:

http://agraria.pro.br/sistema/index.php?journal=agraria\&page=article\&op=view\&path\%5B $\% 5 \mathrm{D}=$ agraria_v9i2a 3518\&path\%5B\%5D=1578 Access: 14 dez. 2015 